tribute to the qualities of the man from one who served as his Private Secretary and $\mathrm{ADC}$ for the last six months of his time as Governor.

The difference between being an Assistant District Commissioner in various up-country districts and an ADC and Private Secretary at Government House in Freetown was dramatic and entailed, amongst other responsibilities, strict attention to details of protocol. Sir George was known to attach great importance to such matters and it was with some trepidation that I tackled the first seating plan for an official Government House Dinner Party. I took my suggestions to Sir George who told me to draw up a chair so that he could go over the plan with me. He then asked me why I had seated each of the guests in the particular order I had placed them. Such was the kindliness of the man that when he had finished analysing the reasons I gave and told me where I was wrong, I suddenly realized what he had not pointed out, namely, that I had only got three places right - his own and those of Lady Beresford-Stooke and myself. In this and many other ways, he delicately built up my confidence and gained my deep respect. I well remember another occasion when I was speaking about a former member of the Royal West African Frontier Force who was being a thorn in the flesh to some up-country administrators, and was therefore not exactly popular with us. Sir George dwelt on the man's qualities as a leader and said that it would be my duty as an administrator, when I went back to district work, to see how his undoubted energies could best be harnessed. Such advice at the start of a colonial service career constantly stood me in good stead.

Sir George never forgot the importance of developments in the then Protectorate of Sierra Leone. He and Lady Beresford-Stooke were indefatigable in visiting as many places as possible when they went 'on trek' and in meeting all the local dignitaries. On many occasions, part, at least, of the journey was done by train and Sir George loved to survey the countryside from a special 'Governor's' seat which was fastened to the front of the engine. When the time came for Sir George to leave Sierra Leone, he told me to start planning for a large farewell party. At that time, it was the correct form for people to sign the Governor's Book when a new Governor took office or when a Governor was leaving. He asked me to keep his plan secret as he wished invitations to be sent to everyone who had had the courtesy to sign his book in the three weeks preceding the date of the party, that is, all who had signed after the announcement that he would be retiring. Well over 1000 invitations were sent out and it was a remarkable tribute to the affection and esteem in which Sir George and Lady Beresford-Stooke were held, that the vast majority were Sierra Leoneans from ordinary walks of life.

M. J. H. WESTCOTT

\title{
DR EVELYN FORDE
}

Long-term members of the Institute will be saddened to hear of the death of Dr Evelyn Forde, widow of Daryll Forde, which took place on 4 January. Though not herself an anthropologist, she always maintained a keen interest in her husband's work, accompanying him to Council meetings in Africa and elsewhere. Even after her husband's death, she kept virtually open house in The Boltons for visiting members of Council and other Africanists connected with the Institute. We shall miss her. 
In accordance with Dr Forde's expressed wishes, the resources of the Daryll Forde Memorial Fund, established a few years ago, are to be made available to the Publications Committee of the Institute to strengthen its book publishing programme.

\section{INTERNATIONAL AFRICAN SEMINAR ON THE PROFESSIONALISATION OF AFRICAN MEDICINE}

The Institute was delighted to be able to hold the first of its new seminars at the University of Botswana, Gaborone, 19-24 September 1983, for the first time in conjunction with the annual meeting of its Executive Council. The seminar was the first international meeting held at the University since it became formally independent and the Vice-Chancellor expressed his particular pleasure that the University had had the opportunity to welcome such a distinguished gathering. A number of seminar participants as well as Executive Council members of the Institute gave lectures and met with students at the University during our presence in Gaborone.

The seminar was opened and made welcome by the Minister of Home Affairs, the Vice-Chancellor, and the Director of the National Institute of Development Research and Documentation. Some forty-seven people from seventeen countries, twelve of which were African, attended the seminar.

The papers are being revised for publication under the editorship of Dr Last and Professor Chavunduka, and it is hoped to publish them in our usual IAI seminar format.

The Institute should like to express its particular thanks and gratitude for the support it has received enabling it to hold this meeting, from the Swedish Agency for Research in Developing Countries; Voluntary and Christian Service; the World Health Organisation; the Commonwealth Foundation; and of course the University of Botswana, its Vice-Chancellor and staff.

\section{HOUSING THE URBAN POOR IN AFRICA}

The International African Institute is presently undertaking a study on Housing the Urban Poor in Africa to provide the background paper to a proposed International African Seminar on this topic to be held in spring 1985, probably in Tunis, under the direction of Professor Peter Lloyd of Sussex University. This initial work is funded by the Social Science Research Council, London, and is being carried out by Dr Phillip Amis who has recently completed his thesis on the commercialisation of unauthorized housing in Nairobi.

The major object of this study is to give an overview and explain the variations in housing provision and tenure and approaches to 'unauthorized' settlements throughout Africa. In particular we are interested in monitoring and evaluating the changes in housing provision and responses to 'unauthorized' settlements within the last twenty years with a view to possible policy alternatives. These changes might include the following: attitudes to rural-urban migration; the emergence of the private rental sector in unauthorized settlements; the nature of access to land by the urban poor, i.e. market or invation; the legal position of unauthorized areas; the possibility of 